\title{
Interpretation of disturbance-induced maturity decrease in marine nematode assemblages by means of the Maturity Index
}

\author{
Tom Bongers ${ }^{1}$, Rob Alkemade ${ }^{2}$, Gregor W. Yeates ${ }^{3}$ \\ ' Department of Nematology, Wageningen Agricultural University, PB 8123, 6700 ES Wageningen, The Netherlands \\ ${ }^{2}$ Delta Institute for Hydrobiological Research, Vierstraat 28, 4401 EA Yerseke, The Netherlands \\ ${ }^{3}$ DSIR Land Resources, Private Bag, Lower Hutt, New Zealand
}

\begin{abstract}
Nematode assemblages offer possibilities for the development of a system to assess the 'quality' of aquatic habitats. Assessment of disturbances in brackish and marine habitats is currently based on abundance patterns or the ratio between Wieser's feeding types $1 \mathrm{~B}$ and $2 \mathrm{~A}$. The Maturity Index, based on nematode life strategies, has been shown to offer good potential to detect disturbances in terrestrial and freshwater habitats. In this study marine nematode genera from the Dutch coast are classified from colonisers to persisters and the versatility of this $c-p$ scale is demonstrated using published data (organic pollution, oil spill, heavy metals and recolonisation). These examples suggest that the nematode Maturity Index may also be useful in assessing disturbance of marine and brackish water sediments.
\end{abstract}

\section{INTRODUCTION}

Acurrent project in the Netherlands ['Nature Developments Volkerakmeer-Zoommeer', run under the auspices of the Institute for Inland Water Management and Waste Water Treatment (RIZA)] monitors changes in benthic nematode assemblages due to freshwater flowing over existing marine sediments. The freshwater both reduces salinity and, in the longer term, deposits pollutants. With an increasing number of nematode samples it became clear that no simple technique existed, either to judge the 'quality' of brackish and marine sediments or to differentiate between stress factors. In the present study such an assessment system is proposed.

For a number of reasons, the nematode assemblage offers prospects for indicating disturbance and assessing the 'quality' of soils and sediments. Nematodes are abundant and often have high species diversity. They are found in all environmental conditions which can support metazoan organisms, with the exception of the pelagic system. Nematodes are permanent members of the benthos and therefore are unable to physically escape from bottom pollution effects. In particular, nematodes offer a potential means of assessing sediment 'quality' in the frequent cases where the pollution level in water and sediment is not evenly balanced.
Nematodes are a group of organisms of diverse biology: their life span varies from several days to several years; a number of species withstand anaerobic conditions; in pollution events nematodes are present after the macrofauna has disappeared; nematodes have a relatively rapid turnover compared to the macrofauna. The short generation time of some nematode species means that the composition of the nematode fauna can react rapidly to disturbances (Ferris \& Ferris 1979, Platt \& Warwick 1980, Platt et al. 1984, Tietjen \& Lee 1984, Lambshead 1986, Bongers 1988).

Marine nematode assemblages are generally compared by diversity indices and other species abundance patterns (Lambshead 1986) regardless of the autecological requirements or identity of the taxa (Vincx 1990). These approaches do not take into account whether, for example, the dominant nematode species is an opportunist like Pellioditis marina with a generation time of 2 d (Hopper et al. 1973) or a large, long-living species such as Leptosomatum bacillatum in which the life span exceeds 1 yr (Bongers 1983). Autecological information has hitherto only been included in the ratio of feeding types (1B/2A) (Lambshead 1986).

Recently an index was developed to assess the condition of terrestrial and freshwater habitats based on the ecological characteristics of nematode taxa (Bongers 
1990). In the present paper the use of this Maturity Index (MI) is extended to assessing the condition of marine and brackish sediments.

\section{THE MATURITY INDEX}

A nematode assemblage is generally composed of tens of species. If such an assemblage is exposed to pollutants or disturbance, the $r$-strategists appear to be relatively tolerant as opposed to those species generally termed K-strategists (Warwick 1986). If K-strategists disappear their resources will soon be utilized by more tolerant species. Therefore one can assume that pollution and other disturbances at a site will cause an increase in the proportion of $r$-strategists there.

Originally $r$-selection was regarded as selection for high population growth in uncrowded populations and $\mathrm{K}$-selection for competitive ability in crowded populations (MacArthur \& Wilson 1967). The meaning of these terms has been broadened to represent character complexes (Parry 1981). Following Bongers (1990), the terms colonisers ( $r$-strategists sensu lato) and persisters (K-strategists sensu lato) are used here to refer to these character complexes.

From the evolutionary point of view supraspecific nematode taxa may be assumed to have developed different survival strategies, resulting in a characteristic association of life-history traits. Compared with Leptosomatidae or Enoplidae the Rhabditidae or Neodiplogasteridae have a high colonisation ability, a short generation time, great population fluctuations, form dauerlarvae to bridge unfavourable conditions, are often small, live in ephemeral habitats, have voluminous gonads, produce many small eggs, are often viviparous and are also relatively tolerant to xenobiotics and other disturbances. This character complex is considered to be characteristic of colonisers and the opposite characters characteristic of persisters. Marine nematode taxa can be placed on an arbitrary c-p scale which ranges from 1 for colonisers to 5 for persisters; a provisional listing is given in the Appendix. The $c-p$ classification is based on the assumptions that the scaling is independent of biotic interactions and that taxa derived from a common ancestor also show similarity regarding their life strategies; the latter is hindered by the fact that the present classification of nematodes does not always reflect monophyletic groups. The $c-p$ scaling, however, is open to testing and modification.

The MI (Bongers 1990) for a nematode assemblage is calculated as the weighted mean of the individual taxon scores:

$$
M I=\sum_{i=1}^{n} v(i) \cdot f(i)
$$

where $v(i)=$ the $c-p$ value of taxon $i$ as given in the Appendix and $f(i)=$ the frequency of that taxon.

In compiling the c-p list given in the Appendix values for the following families were adopted from Bongers (1990): Chromadoridae, Cyatholaimidae, Desmodoridae, Desmoscolecidae, Diplopeltidae, Ethmolaimidae, Ironidae, Leptolaimidae, Linhomoeidae, Microlaimidae, Monhysteridae, Neodiplogasteridae, Rhabditidae and Xyalidae.

Extreme colonisers ( $\mathrm{c}-\mathrm{p}=1$ ) are represented by the Rhabditidae, Neodiplogasteridae and Monhysteridae with generation times of only some days (Bongers 1990); extreme persisters ( $c-p=5$ ) by the Enoplidae and Leptosomatidae with a generation time of 1 yr. Intermediate families were classified based on the character complex defined above, using both published data and information from internal reports, personal communications and our own observations. Nematodes for which $c-p=2$ increase in abundance in stressed or eutrophic conditions but are not mentioned as extreme colonisers, $c-p=3$ is intermediate, and nematodes for which $c-p=4$ are sensitive to stress.

The information gathered enabled us to draw up a preliminary list which was subsequently refined and calibrated by an iterative method to produce the classification presented in the appendix. To complete coverage and to confirm scaling, information was obtained from all available literature, including the case studies mentioned below. In some cases changes were necessary. For example, in a previous paper (Bongers 1990), Leptolamidae were classified at $\mathrm{c}-\mathrm{p}=3$ based on their distribution in terrestrial habitats; in the present list (Appendix) the genus Leptolaimus is given a lower value because of additional information - its dominance in some polluted brackish water habitats in The Netherlands (de Winter 1988, pers. obs.).

Even at genus level there is some uncertainty. The genus Anticoma contains the relatively opportunistic species $A$. acuminata $(c-p=2)$ but also the much larger A. eberthi which probably deserves a higher scaling. According to Lambshead (1986), whereas Leptolaimus scotlandicus can withstand pollution, L. ampullaceus is restricted to cleaner stations. Application of the $c-p$ scale should show empirically whether calibration at genus or species level is necessary. Hopefully, as more information becomes available, it will become clear whether for example Monoposthia mirabilis deserves a $c-p$ value of 4 , based on Boucher (1980), or of 2, based on Lambshead (1986).

In some cases, such as for plant-feeding taxa in terrestrial ecosystems, classification based on the characters mentioned above can be contradictory. Oncholaimids are worthy of special mention here because they combine characteristics of persisters (low reproductive potential, long generation time, few eggs) 
with characteristics of colonisers (occur in eutrophicated and heavily disturbed conditions, extreme dominance). Based on generation time they have to be classified as $c-p=4$ or 5 , based on occurrence 1 or 2 . The following examples provide illustration.

In brackish and marine environments oncholaimids have a long generation time and a rather low reproductive potential. Sometimes, however, they are dominant in a sample, especially at sites with organic matter accumulation or, at least for Adoncholaimus thalassophygas, at $\mathrm{CO}_{2}$-rich sites (Riemann \& Schrage 1988).

Meyers et al. (1970) mention a dominance of $93 \%$ for Metoncholaimus scissus, and densities of 3 million $\mathrm{m}^{-2}$ in turtle grass of Biscayne Bay (Florida, USA) concurrent with blooms of the benthic diatom Pleurosigma balticum. Considerable numbers of almost pure cultures of Oncholaimus dujardinii were reported by Meyers \& Hopper (1967) in fungus-infested wood. In such cases the MI coincides with the c-p value (4) of the Oncholaimidae in general.

In areas of frequently occurring anoxia, Pontonema vulgare aggregates and forms patches 2 to $3 \mathrm{~m}$ in diameter in which the layer of nematodes is several $\mathrm{mm}$ thick, forming white fluffy carpets (Prein 1988). Under such extreme circumstances the MI of this monospecific nematode fauna also approaches 4.

According to Smol et al. (1981), Oncholaimus oxyuris produces a maximum of 37 eggs. Although a predator, it may be one of the dominant species in brackishwater pools and is able to maintain a high density. This species is characterized by its large size, its slow development and long generation time, characters which suggest that $O$. oxyuris has to be considered a relatively $\mathrm{K}$-selected species which seems to contradict its semelparous reproduction ( $\mathrm{Smol}$ et al. 1981).

\section{CASE STUDIES}

In this section some case studies are interpreted which indicate that the scaling of nematode taxa, as presented here, results in a lower Maturity Index as a possible result of organic pollution, heavy metal pollution and oil spill. Furthermore, data are given regarding the behaviour of the MI during the colonisation process of baited sand, effects of sedimentation and MI values in stable habitats.

The studies mentioned here, in particular the example regarding organic pollution, might suggest circularity to some degree because they have been used to complete coverage and to confirm the scaling. If for example Pellioditis marina (the most extreme 'coloniser' with a generation time of 2 to $3 \mathrm{~d}$, and only occurring in eutrophicated conditions) had been found at clean sites, its classification would have been recon- sidered. On the other hand, any circularity would scarcely influence the MI because (1) similar trends are observed if only terrestrial and freshwater taxa are used, and (2) rare taxa occur at low densities and therefore have little influence on the final MI value.

\section{Organic pollution}

The analysis of a pollution gradient in the Clyde estuary (Scotland) by Lambshead (1986) is one of the most thorough pollution studies available. Because of the full species lists, it gives an oppportunity to demonstrate the applicability of the Maturity Index in marine habitats. In Table 1 MIs, calculated according to Eq. (1), are given for each core. The calculated values reveal higher MIs for the reference stations ( 1 and 2) than for the contaminated stations ( 4 to 6 ) (Mann-Whitney test, $\mathrm{p}<0.001$ ). Lambshead (1986) mentions the possibility that benthic currents could have carried contaminants as far northwards as between Stns 2 and 3. The intermediate MI of the core taken at $\operatorname{Stn} 3$ supports this slight contamination.

\section{Oil spill}

Boucher (1980) described the effect of spilled oil on the nematode fauna by comparing the nematode assemblage in 1972-1973 with the assemblage in 1978-1979, after the March 1978 'Amoco Cadiz' oil spill in Brittany (France). In his Table 3 the dominant nematode species (mean dominance $>1 \%$ ) are given. Table 2 presents the values of the MI on comparable dates in the 2 years. The MIs are significantly lower after the oil spill (Mann-Whitney test, $\mathrm{p}<0.05$ ).

Table 2 also illustrates seasonal fluctuation of the MI. In 1972-1973 the November sample has the highest MI. This is in agreement with seasonal fluctuations of MI calculated from Warwick \& Price (1979) whose data from an estuarine mud-flat in the river Lynher estuary, Cornwall, UK, show an MI value 2.76 for October 1972,

Table 1. Maturity Indices for 6 stations in the Clyde estuary Scotland, ( 1 to 3 clean, 4 to 6 polluted), each with 3 replicates (A to C), calculated from Lambshead (1986)

\begin{tabular}{|ccccc|}
\hline & $\mathrm{A}$ & $\mathrm{B}$ & $\mathrm{C}$ & Mean \\
\hline 1 & 2.40 & 2.59 & 2.67 & 2.55 \\
2 & 2.82 & 2.54 & 2.89 & 2.75 \\
3 & 2.31 & & & $2.31^{\mathrm{a}}$ \\
4 & 2.20 & 2.06 & 1.84 & 2.03 \\
5 & $2.08^{\mathrm{b}}$ & 2.15 & 2.15 & 2.13 \\
6 & 2.20 & 2.23 & 2.21 & 2.21 \\
a Only one sample taken & & \\
Close to a domestic sewage pipe \\
\end{tabular}


Table 2. Maturity Indices of the benthic nematode fauna on comparable dates before and after the 'Amoco Cadiz' oil spill in Brittany, France (calculated after Boucher 1980)

\begin{tabular}{|ccccc|}
\hline & May & August & November & March \\
\hline $1972-1973$ & 2.71 & 2.61 & 3.03 & 2.87 \\
$1978-1979$ & 2.43 & 2.46 & 2.35 & 2.35 \\
\hline
\end{tabular}

decreasing to 2.69 in January 1973 and to 2.49 in both April and July 1973.

\section{Colonisation of (baited) sand}

In Tucker's Town Cove, Bermuda, Gerlach (1977) studied the attraction of nematodes to decaying organisms. In the test area samples of $50 \mathrm{ml}$ sand were repeatedly washed and the associated fauna killed by heating or freezing. A piece of frozen sardine was placed in 4 of the 7 samples. The samples were subsequently buried and analyzed after 1 to $11 \mathrm{~d}$. The MIs calculated for both treatment and control are given in Table 3 . The nematode fauna in the surrounding sand at $t=0$ acted as control and in this sample all nematodes had a $c-p$ value $>1$. From the MIs it can be seen that both baited and unbaited sand was colonised immediately. After $1 \mathrm{~d}$ the number of specimens in the baited sand exceeded the unbaited sand by a factor of 2. The MI, however, remained lower (Mann-Whitney test, $p<0.05)$, indicating that 'colonisers' were attracted to, and multiplied in, the baited sand.

\section{Relation between heavy metal load and MI}

Tietjen (1980) studied free-living nematodes in relation to sediment type, organic carbon and heavy metal concentrations in the New York Bight (USA). Based on his Table 4 , in which only species with a mean relative abundance of $>0.5 \%$ are given, MIs were calculated (Table 4). The MIs of the 9 samples show a significant correlation $(p<0.05)$ with each of the heavy metal concentrations (chromium, copper, nickel, lead and zinc) as given in Table 2 of Tietjen (1980).

Using the MI as a basis, 4 groups of stations can be differentiated: stations with MI between 2.40 and 2.50 (4 and 7), a group with MI between 2.20 and 2.30 (10, 16 and 39), a group with $M I$ between 2.10 and 2.15 (25, 32 and 36 ), and a single station with $\mathrm{MI}<1.80$ (33). In Table 5 the mean MIs and heavy metal loads calculated from Table 2 of Tietjen (1980), are given for these groups.

Tietjen (1980, Fig. 2) also presented a dendrogram showing faunal affinities among his stations. Species compositions indicated that the following pairs of stations resembled each other: 16 and 39,4 and 7, 32 and 36. The other stations are distinctive regarding species compositions. The MI values are also similar in these 3 pairs, the mean and ranges being 2.25 (2.21 to 2.29$)$, 2.44 (2.41 to 2.47 ) and $2.13(2.12$ to 2.14$)$.

\section{Sedimentation}

Hopper \& Meyers (1967) studied the influence of strong tidal action in relation to sheltered habitats on the follicolous nematode fauna of Thalassia testudinum in Biscayne Bay. Their exposed site B has an MI of 3.14, whereas the 2 sheltered sites subject to sedimentation (A and C) have lower MIs (2.77 and 2.81 respectively). Thus sedimentation appears to be a more dominant stress factor for these follicolous nematodes than either currents or wave action. Similarly, under brackish conditions in The Netherlands, it appears that sites where silt sedimentation occurs have lower MIs than exposed

Table 3. Maturity Indices during colonisation of washed and baited sand on a Bermuda beach in relation to undisturbed controls (calculated from Gerlach 1977, Table 3)

\begin{tabular}{|ccccccccc|}
\hline & Control & \multicolumn{3}{c}{ Unbaited sand } & \multicolumn{3}{c}{ Baited sand } \\
Days: & 0 & 1 & 4 & 7 & 1 & 2 & 4 \\
\hline $\mathrm{N} / 50 \mathrm{ml}$ & 434 & 56 & 129 & 387 & 147 & 173 & 454 & 830 \\
$\mathrm{MI}$ & 2.70 & 2.34 & 2.40 & 2.52 & 2.12 & 2.03 & 2.11 & 2.25 \\
\hline
\end{tabular}

Table 4. Maturity Indices for sampling stations in the New York Bight Apex, USA, given in Tietjen (1980)

\begin{tabular}{|ccccccccccc}
\hline & & \multicolumn{7}{c}{ Station } & & \\
& 4 & 7 & 10 & 16 & 25 & 32 & 33 & 36 & 39 \\
\hline MI & 2.47 & 2.41 & 2.29 & 2.29 & 2.10 & 2.12 & 1.78 & 2.14 & 2.21 \\
\hline
\end{tabular}


Table 5. Relation between Maturity Indices and heavy metal concentrations (ppm) as given by Tietjen (1980) for stations in the New York Bight Apex

\begin{tabular}{rrrrrr|}
\hline $\mathrm{MI}$ & $\mathrm{Cr}$ & $\mathrm{Cu}$ & $\mathrm{Ni}$ & $\mathrm{Pb}$ & $\mathrm{Zn}$ \\
\hline 2.44 & 3.5 & 3.0 & 3.0 & 8.3 & 18.3 \\
2.26 & 5.3 & 5.7 & 5.7 & 17.0 & 25.3 \\
2.12 & 15.0 & 34.0 & 14.8 & 35.2 & 82.5 \\
1.78 & 302.0 & 360.5 & 47.0 & 141.5 & 580.0 \\
\hline
\end{tabular}

sandy sites (Bongers \& Van de Haar 1990). The pollution-induced shift in nematode assemblages of sandy sediments towards nematode assemblages that normally inhabit silty sediments might be explained by the tolerance of those nematodes to pollutants, although we realize that the effects of pollution and effects of sediment granulometry are very often difficult to distinguish, as noted by Heip et al. (1985).

\section{Stable habitats}

Although ephemeral habitats have a predominance of colonisers, this does not mean that physically stable habitats always have a high MI. Even under deep-sea conditions carcasses of macrofauna provide niches for opportunistic species (i.e. $r$-strategists with low c-p values). The deep-sea fauna of the Hatteras Abyssal Plain and Puerto Rico Trench (2200 to $8400 \mathrm{~m}$ ), as reported by Tietjen (1989), has MIs of 2.80 to 2.93 , with a somewhat lower value (2.68) for Stn 2 in the Puerto Rico Trench where Xyalidae and other Monhysterida families make up $40 \%$ of the nematode fauna, and Theristus $(c-p=2)$ is dominant $(26 \%)$.

\section{DISCUSSION}

Hitherto the only characterization of the nematode fauna which includes autecological information has been the division into feeding types (Wieser 1953) and the ratio between types $1 \mathrm{~B}$ and $2 \mathrm{~A}$, as proposed by Lambshead (1986). Increasing knowledge of actual feeding practices has refined understanding of Wieser's feeding types and it appears that the relation between buccal cavity and feeding type assignment is rather complex. For example, although Metoncholaimus scissus is usually allocated to type $2 \mathrm{~B}$ regarding the morphology of the buccal cavity, Meyers et al. (1970) reported that it obtains its primary food via random ingestion of fine sediment and detrital material which suggests allocation to type $1 \mathrm{~B}$ on a functional basis. According to Wieser (1959) the larger leptosomatids such as Thoracostoma s.l. $(\mathrm{c}-\mathrm{p}=5)$ belong to type 2A, together with Desmodora $(\mathrm{c}-\mathrm{p}=2)$ and Microlaimus ( $\mathrm{c}-\mathrm{p}=2$ ). Furthermore Eudiplogaster ( $\mathrm{c}-\mathrm{p}$ =1), Oncholaimus ( $\mathrm{c}-\mathrm{p}=4)$ and Cylicolaimus $(\mathrm{c}-\mathrm{p}=5)$ also belong to the same feeding type (2B). Although it is not always possible to allocate a species to one of the feeding types based exclusively on the buccal cavity division into feeding types will remain an important tool in characterizing ecosystems, the purpose for which this division was originally developed. We have the impression that the MI, through representing a broader character complex, might give considerable additional information regarding disturbance and colonisation process.

To obtain some insight into the relation between feeding groups and MIs, nematode genera known from The Netherlands were assigned to one of the feeding types and the mean MI for each feeding type was calculated. The mean $\mathrm{MI}$ for type $1 \mathrm{~A}$ is 3.7 , for $1 \mathrm{~B} 2.1$ and for $2 \mathrm{~A}$ and $2 \mathrm{~B}$ about 3.0. For the genera listed in Lambshead (1986) the same trend is observed: 3.2, 2.5, 2.6 and 2.7 respectively. Thus dominance of $1 \mathrm{~B}$ species is associated with a lower $\mathrm{MI}$ than a dominance of $1 \mathrm{~A}$ species. This agrees with the findings of Vincx (1989) who found that the proportion of $1 \mathrm{~A}$ species is larger in well-sorted, clean sand and that the proportion of $1 \mathrm{~B}$ decreases in coarser sediments and is very high in silty bottoms loaded with organic carbon. The suggestion of Ferris \& Ferris (1979) of combining types $1 \mathrm{~A}$ and $1 \mathrm{~B}$, because of difficulties in assigning certain species to one of these groups, devaluates the information obtained from the $1 \mathrm{~A}+\mathrm{B} / 2 \mathrm{~A}$ ratio.

The case studies suggest that the MI is decreased by pollution (sewage waste, oil, heavy metals) but increases during the colonisation process. A similar situation was found in terrestrial and freshwater habitats (Bongers 1990). Such shifts in the MI reflect deterioration or recovery of a nematode assemblage and, because of the ecological diversity of the nematode fauna, represent the whole habitat from which the sample is taken.

From the examples given above both disturbance and an increase in decomposition rate can be seen to result in a decreasing $\mathrm{MI}$. If we assume that a stable habitat is characterized by a range of species with narrow ecological niches, disturbance influences the most sensitive species and the niches of species adversely affected will remain vacant or will be filled by less specialised species and/or species with a higher reproductive potential; this will result in a decreasing MI. On the other hand, an increasing quantity of food will favour fast-reproducing species, also resulting in a decreasing MI.

Colonisation and restoration of a habitat can be seen as replacement of unspecialised species by (more) specialised species. It is remarkable that the most 
extreme colonists, such as Rhabditidae and Diplogasteridae, are not replaced by persisters as long as the organic input remains high. In areas subject to a constantly high input of organic waste [e.g. the waste originating from potato-flour factories (Bouwman 1983)] typical diplogasterid colonisers are not replaced by persisters. The same phenomenon has been observed for plant-parasitic nematodes in terrestrial ecosystems (Boag \& Alphey 1988); among bacterial feeders Plectidae and Cephalobidae only replace the less efficient Rhabditidae if food supply decreases (Schiemer 1983).

Appendix. Provisional c-p values for Dutch brackish and marine nematode families and genera, in alphabetical order; the classification is that of Platt \& Warwick (1983), and, for Secernentea, Bongers (1988). The following types of data were used in allocating c-p values to families: (i) Basal information obtained from studies in The Netherlands on the nematode fauna in oilpolluted Rotterdam harbours (Tamis 1986), nematodes in a pollution gradient in Lake Vossemeer (Jacobs 1987), nematodes in polluted Rhine sediments (Bongers \& Van de Haar 1990), and a monitoring study in the Western Scheldt (De Winter 1988). (ii) Personal observations from current colonisation and decomposition studies on Spartina leaves (Alkemade) and other observations on nematodes in marine and brackish water habitats (Bongers). (iii) Personal communications: unpublished species lists of brackish and marine nematodes from the Eastern Scheldt (Loof), observations on biology of nematodes in the Ems Dollard estuary (Bouwman), observations by De Winter and Van de Haar and general discussions with the participants of the 7 th International Symposium on Aquatic Nematodes (Yerseke, NL)

\begin{tabular}{|c|c|c|c|c|c|c|c|}
\hline Actinonema & 4 & Desmoscolex & 4 & Metepsilonema & 4 & Quadricoma & 4 \\
\hline Adoncholaimus & 4 & Dichromadora & 2 & Metoncholaimus & 4 & Rhabdocoma & 4 \\
\hline Aegialalaimidae & 4 & Diplolaimella & 1 & Microlaimidae & 3 & Rhabditidae & 1 \\
\hline Aegialoalaimus & 4 & Diplopeltidae & 3 & Microlaimus & 2 & Rhabdodemania & 4 \\
\hline Amphimonhysiera & 2 & Dolicholaimus & 2 & Molgolaimus & 3 & Rhabdodemaniidae & 4 \\
\hline Anoplostoma & 2 & Dracognomus & 4 & Monhystera & 1 & Rhips & 3 \\
\hline Anoplostomatidae & 2 & Draconematidae & 4 & Monhysteridae & 1 & Rhynchonema & 3 \\
\hline Anticoma & 2 & Echinotheristus & 2 & Monoposthia & 3 & Richtersia & 3 \\
\hline Anticomidae & 2 & Eleutherolaimus & 2 & Monoposthiidae & 3 & Sabatieria & 2 \\
\hline Antomicron & 3 & Enchelidiidae & 4 & Nemanema & 4 & Selachinematidae & 3 \\
\hline Araeolaimus & 3 & Enoplidae & 5 & Neochromadora & 2 & Sigmophoranema & 3 \\
\hline Ascolaimus & 2 & Enoploides & 2 & Neodiplogasteridae & 1 & Siphonolaimidae & 3 \\
\hline Atrochromadora & 4 & Enoplolaimus & 2 & Neotonchoides & 3 & Siphonolaimus & 3 \\
\hline Axonolaimidae & 2 & Enoplus & 5 & Neotonchus & 2 & Southerniella & 3 \\
\hline Axonolaimus & 2 & Epsilonema & 4 & Odontophora & 2 & Sphaerolaimidae & 3 \\
\hline Bathylaimus & 2 & Epsilonematidae & 4 & Odontophoroides & 2 & Sphaerolaimus & 3 \\
\hline Bolbolaimus & 3 & Ethmolaimidae & 3 & Oncholaimellus & 3 & Spilophorella & 2 \\
\hline Calomicrolaimus & 2 & Euchromadora & 3 & Oncholaimidae" & 4 & Spirinia & 3 \\
\hline Calyptronema & 4 & Eurystomina & 4 & Oncholaimus & 4 & Stephanolaimus & 4 \\
\hline Camacolaimus & 3 & Gammanema & 3 & Onyx & 3 & Stylotheristus & 2 \\
\hline Ceramonematidae & 3 & Gonionchus & 4 & Oxyonchus & 2 & Symplocostoma & 4 \\
\hline Chaetonema & 2 & Greeffiella & 4 & Oxystomina & 4 & Synonchus & 5 \\
\hline Choniolaimus & 3 & Halalaimus & 4 & Oxystominidae & 4 & Syringolaimus & 4 \\
\hline Chromadora & 3 & Halaphanolaimus & 3 & Paracanthonchus & 2 & Terschellingia & 3 \\
\hline Chromadorella & 3 & Halichoanolaimus & 3 & Paracyatholaimoides & 3 & Thalassoalaimus & 4 \\
\hline Chromadoridae & 3 & Haliplectidae & 3 & Paracyatholaimus & 2 & Theristus & 2 \\
\hline Chromadorina & 3 & Haliplectus & 3 & Paralinhomoeus & 2 & Thoracostoma & 5 \\
\hline Chromadorita & 3 & Hypodontolaimus & 4 & Parallelocoilas & 3 & Thoracostomopsidae" & 2 \\
\hline Chromaspirina & 4 & Ironidae & 4 & Paralongicyatholaimus & 3 & Trefusia & 4 \\
\hline Cobbia & 3 & Ixonema & 4 & Paramesonchium & 2 & Trefusiidae & 4 \\
\hline Comesomatidae & 2 & Laimella & 2 & Paramonohystera & 2 & Trichotheristus & 2 \\
\hline Crenopharynx & 4 & Latronema & 3 & Pellioditis & 1 & Tricoma & 4 \\
\hline Cyartonema & 3 & Leptolaimidae ${ }^{\bullet}$ & 3 & Perepsilonema & 4 & Trileptium & 2 \\
\hline Cyatholaimidae & 3 & Leptolaimus & 2 & Phanodermatidae & 4 & Tripyloides & 2 \\
\hline Cyatholaimus & 3 & Leptonemella & 4 & Polygastrophora & 4 & Tripyloididae & 2 \\
\hline Cylicolaimus & 5 & Leptosomatidae & 5 & Pomponema & 4 & Tubolaimoides & 3 \\
\hline Dagda & 3 & Leptosomatum & 5 & Pontonema & 4 & Tubolaimoididae & 3 \\
\hline Daptonema & 2 & Linhomoeidae ${ }^{\bullet}$ & 2 & Praeacanthonchus & 4 & Valvaelaimus & 2 \\
\hline Dasynemoides & 3 & Linhomoeus & 2 & Prochaetosoma & 4 & Viscosia & 3 \\
\hline Deontolaimus & 3 & Mesacanthion & 3 & Prochromadorella & 2 & Wieseria & 4 \\
\hline Desmodora & 2 & Metachromadora & 2 & Pselionema & 3 & Xyala & 3 \\
\hline Desmodoridae" & 3 & Metadesmolaimus & 2 & Pseudocella & 5 & Xyalidae" & 2 \\
\hline Desmolaimus & 2 & Metalinhomoeus & 2 & Pseudonchus & 3 & & \\
\hline Desmoscolecidae & 4 & Metaparoncholaimus & 4 & Ptycholaimellus & 3 & & \\
\hline
\end{tabular}


The c-p list presented in this paper is a first attempt and has to be validated against further data. Moreover, the values are subjective because they are based on a complex of characteristics; if a value was only based on eutrophication then additional information (e.g. based on cadmium) might result in another scaling. Maturity Index values give a rough indication of disturbances, but are unable to identify the dominant stress factor. However, a set of comparable single-factor indices would provide a starting point for identification of dominant stress factors and further work along these lines is in progress.

The seasonal fluctuation of the MI deserves closer study. Egg deposition in marine nematodes may be of 2 types (Warwick \& Buchanan 1971): either the females store a large number of eggs and then release them in a mass and subsequently die, or eggs are laid continuously. Nematodes with a life span of a year (persisters) are generally of the first type, e.g. spawning of Enoplus communis takes place in spring (Wieser \& Kanwisher 1960). Thus the MI in a sample may suddenly increase after such a spawning period, particularly if persisters become dominant. This phenomenon also influences other ecosystem parameters such as diversity, evenness and the relation between feeding types.

Additional studies must show if it is possible to develop an 'ecological sediment typology' based on nematode assemblages and to calculate related ecosystem parameters (MI, diversity, evenness etc.). Seasonal environmental fluctuations must be allowed for. The ultimate aim is to apply such ecological typology as a reference for the assessment of a single sample. Development of such a typology has recently been undertaken regarding terrestrial habitats (Bongers et al. 1989), freshwater habitats (Bongers \& Van de Haar 1990) and marine sediments (Vincx 1989).

In the 'Introduction' some advantages of using nematodes to assess the 'quality' of sediments and other soils were mentioned. There are also some practical aspects which must be emphasized. Nematodes are easily collected and isolated. Using techniques applied in plant nematology and new techniques such as mounting on mass slides, time-consuming handpicking has become superfluous (Bongers \& Van de Haar 1990). After a sediment sample arrives at the lab the MI can be calculated within $2 \mathrm{~h}$.

An advantage of the use of the MI is that identification to species appears to be unnecessary. Often identification at family level is satisfactory and, although not yet studied in detail, classification of 75 specimens should give a satisfactory estimate of the MI.

There is a growing realization that from the environmental viewpoint the only baselines for assessing the 'quality' of soils and sediments are biological ones and that the nematode fauna has the potential for the development of an efficient system to assess the 'quality' of terrestrial and temporarily submerged soils as well as inland and marine sediments. We hope that the approach presented here will stimulate the use of the nematode fauna in environmental studies.

Acknowledgements. The authors thank those publishers with a far-sighted editorial policy, because without full species lists this study would not have been possible. The authors also express their gratitude to the participants of the 7 th International Symposium on Aquatic Nematodes (Yerseke, The Netherlands) for stimulating discussions.

\section{LITERATURE CITED}

Boag, B., Alphey, T. J. W (1988). Influence of interspecific competition on the population dynamics of migratory plant-parasitic nematodes with $\mathrm{r}$ and $\mathrm{K}$ survival strategies. Rev. Nematol. 11 321-326

Bongers, T. (1983). Bionomics and reproductive cycle of the nematode Leptosomatum bacillatum living in the sponge Halichondria panicea. Neth. J. Sea Res. 17: 39-46

Bongers, T (1988). De Nematoden van Nederland. Natuurhistorische Bibliotheek KNNV. Nr. 46. Pirola, Schoorl

Bongers, $T$ (1990). The maturity index: an ecological measure of environmental disturbance based on nematode species composition. Oecologia 83: 14-19

Bongers, T., de Goede, R. G. M., Kappers, F. I., Manger, R. (1989). Ecologische typologie van de Nederlandse bodem op basis van de vrijlevende nematodenfauna. National Institute for Public Health and Environmental Protection, Bilthoven NL. Rapportnr. 718602002

Bongers, T., Van de Haar, J. (1990). On the potential of basing an ecological typology of aquatic sediments on the nematode fauna: an example from the river Rhine. Hydrobiol. Bull. 24 (1): $37-45$

Boucher, G. (1980). Impact of Amoco Cadiz oil spill on intertidal and sublittoral meiofauna. Mar. Pollut. Bull. 11: 95-101

Bouwman, L. A. (1983). Systematıcs, ecology and feeding biology of estuarine nematodes. Biologisch Onderzoek Eems-Dollard Estuarium (BOEDE), Publ. \& Versl. no. 3

Ferris, V. R., Ferris, J. M. (1979). Thread worms (Nematoda). In: Hart, C. W., Fuller, S. L. H. (eds.) Pollution ecology of estuarine environments. Academic Press, London, p. 1-33

Gerlach, S. A. (1977). Atraction to decaying organisms as a possible cause for patchy distribution of nematodes in a Bermuda beach. Ophelia 16 (2): 151-165

Heip, C., Vincx, M., Vranken, G. (1985). The ecology of marine nematodes. Oceanogr. mar. Biol. A. Rev. 23: $399-489$

Hopper, B. E., Fell, J. W., Cefalu, R. C. (1973). Effect of temperature of life cycles of nematodes associated with mangrove (Rhizophora mangle) detrital systems. Mar. Biol. 23: 293-296

Hopper, B. E., Meyers, S. P. (1967). Follicolous marine nematodes on turtle grass, Thalassia testudinum, König, in Biscayne Bay, Florida. Bull. mar. Sci. 17 (2): 471-517

Jacobs, L. J. (1987). Inleiding tot de biologische kwaliteitsbeoordeling van onderwaterbodems in Nederland door middel van de nematofauna. Report Nem. Dept. Wag. Agr Univ., DBW-RIZA, Lelystad

Lambshead, P. J. D. (1986). Sub-catastrophic sewage and industrial waste contamination as revealed by marine 
nematode faunal analysis. Mar. Ecol. Prog. Ser 29: $247-260$

MacArthur, R. H., Wilson, E. O. (1967). The theory of island biogeography. Princeton University Press, Princeton

Meyers, S. P., Hopper, B. E. (1967). Studies on marine fungalnematode associations and plant degradation. Helgoländer wiss. Meeresunters. 15: 270-281

Meyers, S. P., Hopper, B. E., Cefalu, R. (1970). Ecological investigations of the marine nematode Metoncholaimus scissus. Mar Biol. 6 (1): 43-47

Parry, G. D. (1981). The meanings of $r$ - and K-selection. Oecologia 48: 260-264

Platt, H. M., Warwick, R. M. (1980). The significance of freeliving nematodes to the littoral ecosystem. In: Price, J. H., Irvine, D. E. G., Farnham, W. F. (eds.) The shore environment, 2. Ecosystems. Academic Press, London, p. $729-759$

Platt, H. M., Warwick, R. M. (1983). Freeliving marine nematodes. Part I. British enoplids. Synopses of the British Fauna (New Series) No. 28. Cambridge University Press, Cambridge

Platt, H. M., Shaw, K. M., Lambshead, P. J. D. (1984). Nematode species abundance patterns and their use in the detection of environmental perturbations. Hydrobiologia 118: 59-66

Prein, M. (1988). Evidence for a scavening lifestyle in the freeliving nematode Pontonema vulgare (Enoplida, Oncholaimidae). Kieler Meeresforsch., Sonderh. 6: 389-394

Riemann, F., Schrage, M. (1988). Carbon dioxide as an attractant for the free-living marine nematode Adoncholaimus thalassophygas. Mar. Biol. 98: 81-85

Schiemer, F. (1983). Comparative aspects of food dependance and energetics of free living nematodes. Oikos $41 \quad 32-42$

Smol, N. Heip, C., Govaert, M. (1981). The life cycle of Oncholaimus oxyuris (Nematoda) in its habitat. Annls Soc r. zool. Belg. 2: 87-103

Tamis, W. L. M. (1986). Nematoden in Vlaardings havenslib en in papierslurrie in het Apeldoorns Kanaal. Hydro-

This article was presented by Dr R.M. Warwick, Plymouth, UK biologisch Adviesbureau Klink bv, Wageningen. Rapp. \& Meded. 22

Tietjen, J. H. (1980). Population structure and species composition of the free-living nematodes inhabiting sands of the New York Bight Apex. Estuar. coast. mar. Sci. 10: 61-73

Tietjen, J. H. (1989). Ecology of deep-sea nematodes from the Puerto Rico Trench and Hatteras Abyssal Plain. Deep Sea Res. 36 (10): 1579-1594

Tietjen, J. H., Lee, J. J. (1984). The use of free-living nematodes as a bioassay for estuarine sediments. Mar. environ. Res. 11: 233-251

Vincx, M. (1989). Free-living marine nematodes from the southern bight of the North Sea. Academia Analecta. Meded. K. Acad. Wet. Lett. Schone Kunsten Belg. Kl. Wet. 51: 39-70

Vincx, M. (1990). Diversity of the nematode communities in the southern bight of the North Sea. Neth. J. Sea Res. 25: $181-188$

Warwick, R. M. (1986). A new method for detecting pollution effects on marine macrobenthic communities. Mar Biol. 92: $557-562$

Warwick, R. M., Buchanan, J. B. (1971). The meiofauna off the coast of Northumberland II. Seasonal stability of the nematode population. J. mar. biol. Ass. U.K. 51: 355-362

Warwick, R. M., Price, R. (1979). Ecological and metabolic studies on free-living nematodes from an estuarine mudflat. Estuar coast. mar. Sci. 9: 257-271

Wieser, W. (1953). Die Beziehung zwischen Mundhölengestalt, Ernährungsweise und Vorkommen bei freilebenden marinen Nematoden. Ark. Zool. (2) 4:439-484

Wieser, W. (1959). Free-Iiving nematodes IV Reports of the Lund University Chile Expedition 1948-49. Lunds Universitets Arsskrift. N.F. Avd.2 Bd.. 55. Nr. 5

Wieser, W. Kanwischer, J. (1960). Growth and metabolism in a marine nematode, Enoplus communis Bastian. Z. vergl. Physiol. 43: 29-36

Winter, W de (1988). Nematodenfauna van het Volkerakmeer/Zoommeer Rep. Nem. Dept. Wag. Agric. Univ., DBW-RIZA, Dordrecht

Manuscript first received: September 30, 1990

Revised version accepted: July 1, 1991 